\title{
Prevalence of Blindness and Visual Impairment in Nigeria: The National Blindness and Visual Impairment Survey
}

\author{
Fatima Kyari, ${ }^{1}$ Murtby V. S. Gudlavalleti, ${ }^{2}$ Selvaraj Sivsubramaniam, ${ }^{2}$ Clare E. Gilbert, ${ }^{2}$ \\ Mohammed M. Abdull, ${ }^{3}$ Gabriel Entekume, ${ }^{4}$ Allen Foster, ${ }^{2}$ and the Nigeria National \\ Blindness and Visual Impairment Study Group ${ }^{5}$
}

Purpose. To determine the prevalence of blindness and visual impairment among adults aged $\geq 40$ years in Nigeria.

Methods. Multistage, stratified, cluster random sampling with probability proportional to size procedures was used to identify a cross-sectional nationally representative sample of 15,027 persons $\geq 40$ years of age from all 36 states in Nigeria and the Federal Capital Territory. Distance visual acuity (VA) was measured with a reduced $\log$ MAR tumbling-E chart at 4 and $1 \mathrm{~m}$. Presenting and best corrected visual acuities were recorded. Autorefraction was performed in all examined adults. Clinical evaluations included examination under dilation for those with presenting vision $<6 / 12$ in either eye.

RESults. In the study, 15,122 persons aged $\geq 40$ years were enumerated and 13,599 (89.9\%) examined. Prevalence of blindness $(<20 / 400$ in the better eye $)$ and severe visual impairment $(<20 / 200-20 / 400$; presenting vision) was $4.2 \%(95 \%$ confidence interval $[\mathrm{CI}]: 3.8 \%-4.6 \%)$ and $1.5 \%$ (95\% CI: $1.3 \%-$ $1.7 \%)$, respectively. Blindness was associated with increasing age, being female, poor literacy, and residence in the North. Participants residing in the South West had the lowest prevalence while those in the North East had the highest prevalence of blindness. It is estimated that 4.25 million adults aged $\geq 40$ years have moderate to severe visual impairment or blindness $(<20 / 63$ in the better eye).

Conclusions. There is a high prevalence of blindness and severe visual impairment among those aged $\geq 40$ years in Nigeria. Significant differences exist between the geopolitical zones and emphasis should be on ensuring eye services across Nigeria, which means that planning at the regional level is necessary. (Invest Ophthalmol Vis Sci. 2009;50:2033-2039) DOI:10.1167/iovs.08-3133

From the ${ }^{1}$ National Eye Centre, Kaduna, Nigeria; the ${ }^{2}$ International Centre for Eye Health, London School of Hygiene and Tropical Medicine, London, United Kingdom; the ${ }^{3}$ Specialist Hospital, Bauchi, Nigeria; and ${ }^{4}$ Vision Health Services, Ikeja, Lagos State, Nigeria.

${ }^{5}$ The Nigeria National Blindness and Visual Impairment Study Group also consisted of: Mansur M. Rabiu, Abubakar Tafida, Christian Ezelum, Olufunmilayo Bankole, and Abudallahi Imam.

Supported by Sightsavers International, Christian Blind Mission, and Vellux Stiftung.

Submitted for publication November 10, 2008; revised December 9, 2008; accepted March 13, 2009.

Disclosure: F. Kyari, None; M.V.S. Gudlavalleti, None; S. Sivsubramaniam, None; C.E. Gilbert, None; M.M. Abdull, None; G. Entekume, None; A. Foster, None

The publication costs of this article were defrayed in part by page charge payment. This article must therefore be marked "advertise$m e n t "$ in accordance with 18 U.S.C. $\$ 1734$ solely to indicate this fact.

Corresponding author: Murthy V. S. Gudlavalleti, International Centre for Eye Health, London School of Hygiene and Tropical Medicine, Keppel Street, London, UK WC1E7HT gvs.murthy@1shtm.ac.uk.
The World Health Organization (WHO) states that there is a 1 paucity of data on the prevalence and causes of blindness and visual impairment in African countries, as very few have data at the national level. ${ }^{1}$ Such data are essential for planning services for the realization of the goals of VISION2020: the global Right to Sight initiative.

Nigeria is the most populous country in Africa with an estimated population of 140 million $^{2}$ which also makes it the ninth most populous country in the world. ${ }^{3}$ Despite its size, there has been no national estimate of the prevalence and causes of blindness and visual impairment. Most data used for planning eye care services have been generated from hospitalbased studies or special population groups, ${ }^{4-8}$ or from small, focal surveys. ${ }^{9-16}$ Such data cannot be extrapolated to the entire country, as the population is culturally, ethnically, economically, and geographically very diverse. More than 500 languages are spoken in Nigeria, which is home to more than 200 ethnic groups. ${ }^{3}$ GDP per capita was 1150 US\$ in 2006 with $70.2 \%$ of the population living in poverty ( $<1$ US\$ per day). ${ }^{17}$

It is imperative that scientifically valid baseline data be generated for the whole country so that implementation of VISION2020 programs can be needs based. We therefore decided to undertake the Nigeria National Blindness and Visual Impairment survey, which would provide the evidence needed by the Federal Government for planning eye care services. The primary objective of the survey was to determine the prevalence and causes of blindness and visual impairment among adults aged 40 years and older in a nationally representative sample.

\section{MeTHODS}

A detailed description of the sampling, enumeration, visual acuity (VA), and ocular examination procedures has already been published. ${ }^{18}$ The methodology was similar to surveys undertaken recently in Bangladesh and Pakistan. ${ }^{19,20}$

Ethical approval for the study was provided by the London School of Hygiene and Tropical Medicine and the Federal Government of Nigeria. The study adhered to the tenets of the Declaration of Helsinki. Written informed consent was obtained from the subjects after explanation of the nature of the study.

The country is divided into six administrative zones, which are called geopolitical zones (GPZs), 36 states and the Federal Capital Territory of Abuja. Each state is subdivided into local government authorities (LGAs), which are the smallest administrative unit. There are 774 LGAs in the country.

\section{Sample Size}

The sample size was calculated based on an assumed prevalence of blindness (VA of $<20 / 400$ in the better eye) of $5 \%$ among those aged $\geq 40$ years, a relative precision of $0.5 \%$, a $95 \%$ confidence interval $(\mathrm{CI})$, design effect of 1.75 , and a response rate of $85 \%$. An estimate of $5 \%$ was used based on earlier small-scale studies in Nigeria and discussion with 
TABLE 1. Survey Response Rates in Different Regions of Nigeria

\begin{tabular}{lcccccc}
\hline \multicolumn{1}{c}{ GPZ } & $\begin{array}{c}\text { Total } \\
\text { Clusters }\end{array}$ & $\begin{array}{c}\text { \% Rural } \\
\text { Clusters }\end{array}$ & $\begin{array}{c}\text { \% Urban } \\
\text { Clusters }\end{array}$ & Enumerated & Examined* & $\begin{array}{c}\text { Response } \\
\text { Rate \% }\end{array}$ \\
\hline North Central & 45 & $66.7(30)$ & $32.6(15)$ & 2,287 & 2,032 & 88.8 \\
North East & 41 & $74.5(38)$ & $25.5(13)$ & 1,959 & 1,727 & 88.2 \\
North West & 80 & $75.7(53)$ & $24.3(17)$ & 3,949 & 3,596 & 91.1 \\
South East & 36 & $80.5(29)$ & $19.4(7)$ & 1,778 & 1,662 & 93.5 \\
South South & 45 & $73.3(33)$ & $26.7(12)$ & 2,074 & 1,852 & 89.3 \\
South West & 63 & $68.2(43)$ & $31.7(20)$ & 3,075 & 2,730 & 88.8 \\
Total & 310 & $72.9(226)$ & $27.1(84)$ & 15,122 & 13,599 & 89.9 \\
\hline
\end{tabular}

* In eight examined individuals, VA was missing, and these individuals have been excluded from the remaining tables.

Federal Ministry officials in Nigeria. $6,11,12,21$ The final calculated sample size was 15,027 persons $\geq 40$ years of age.

\section{Sampling Process}

Multistage, stratified, cluster random sampling with probability proportional to size (PPS) procedures were used to identify a cross-sectional, nationally representative sample. The sample covered all 36 states and the Federal Capital Territory of Abuja. The population included in the sampling frame in each state was based on the actual population of the state, such that more populous states had more clusters compared with less populated states. In each cluster location, the center of the cluster was located, and a random start made by spinning a bottle. The enumeration then started from the first inhabited house on the left hand-side. The enumeration process continued until 50 adults aged $\geq 40$ years, normally resident (continuous residence for at least the past 3 months) were identified. In the last household, if more than one eligible adult was available, all were included, even if the total exceeded 50 . In small villages, if there were fewer than 50 eligible adults, the nearest village was included. Separate sampling frames were constructed for urban and rural areas, and clusters were identified randomly for urban and rural areas separately. The process resulted in identification of 310 clusters across the country, of which 226 were rural and 84 were urban

After obtaining written informed consent, we collected personal and demographic data of all eligible participants at the time of enumeration, and the participants were invited to attend a convenient location within the cluster for clinical examination. Enumerated individuals who did not report to the examination site were followed up three times and offered an examination at their homes in the final instance before they were deemed nonrespondents. Nonrespondents were not replaced.

Clinical Examination. Personal and demographic data collected during enumeration were verified by a trained interviewer. Height, weight, and blood pressure were each measured three times, and all participants underwent distance VA measurement with a reduced logMAR tumbling-E chart. ${ }^{22,23}$ The reduced logMAR E chart has three tumbling-E optotypes per line, and a border surround that con- forms to accepted contemporary design principles. ${ }^{23}$ These charts have been used in the earlier surveys in Bangladesh and Pakistan. ${ }^{19,20}$ Visual acuity was measured at 4 and $1 \mathrm{~m}$ (if necessary) by trained ophthalmic nurses in a shaded area outdoors. Individuals who could not read at least 2 letters on the top line of the chart at $4 \mathrm{~m}$ were tested at $1 \mathrm{~m}$ by the nurses, while those who could not read the letters even at $1 \mathrm{~m}$ were tested for counting fingers, hand movements, and perception of light by an ophthalmologist. Each eye was first tested separately, and then vision was recorded with both eyes. Based on presenting VA, individuals were either given a red card (VA $\leq 6 / 12$ in either eye) or a green card (VA $>6 / 12$ in both eyes). All participants, with green or red cards had a basic eye examination by an ophthalmologist, followed by automated refraction (ARKM-100; Takagi Seiko, Nagano-Ken, Japan) and A-scan biometry performed by a trained optometrist. Red card participants, and one in eight with a green card, were then examined in more detail, including retesting VA and subjective refraction with the autorefraction results placed in a trial lens frame. Simple treatments and spectacles were provided to those needing them free of charge at the study site, and those requiring further investigations or surgery were referred to the nearest eye hospital.

Initial training was undertaken over 2 weeks, and training sessions were repeated for each GPZ (two weeks each). A pilot study was conducted in each GPZ. Interobserver agreement studies were conducted for the ophthalmic nurses and the ophthalmologists periodically throughout the study. Data were collected over a 30-month period from January 2005 to July 2007. The core team (four ophthalmologists and two optometrists) remained constant over the 30 months while other personnel were recruited locally for each GPZ so that local languages and knowledge could be used.

Definitions. World Health Organization categories of visual loss were used,${ }^{24}$ with the addition of a category, near normal, which has been used in other recent surveys. This scheme allows international comparisons to be made. ${ }^{25-27}$

Blindness: presenting VA (with glasses for distance if normally worn or unaided if glasses for distance not worn) of $<20 / 400$ in the better eye.

TABLE 2. Age and Sex Distribution of Study Population

\begin{tabular}{|c|c|c|c|c|c|c|c|c|c|c|c|c|}
\hline \multirow[b]{3}{*}{ Age Groups (y) } & \multicolumn{4}{|c|}{ Men } & \multicolumn{4}{|c|}{ Women } & \multicolumn{4}{|c|}{ Total } \\
\hline & \multicolumn{2}{|c|}{ Enumerated } & \multicolumn{2}{|c|}{ Examined } & \multicolumn{2}{|c|}{ Enumerated } & \multicolumn{2}{|c|}{ Examined } & \multicolumn{2}{|c|}{ Enumerated } & \multicolumn{2}{|c|}{ Examined } \\
\hline & $N$ & $\%$ & $\boldsymbol{N}$ & $\%$ & $N$ & $\%$ & $\boldsymbol{N}$ & $\%$ & $\boldsymbol{N}$ & $\%$ & $\boldsymbol{N}$ & $\%$ \\
\hline $40-49$ & 2,507 & 35.7 & 2,084 & 33.4 & 3,270 & 40.4 & 2805 & 38.2 & 5,777 & 38.2 & 4889 & 36.0 \\
\hline $50-59$ & 1,840 & 26.2 & 1,649 & 26.4 & 2,095 & 25.9 & 1928 & 26.2 & 3,935 & 26.0 & 3577 & 26.3 \\
\hline $60-69$ & 1,405 & 19.9 & 1,306 & 20.9 & 1,529 & 18.9 & 1467 & 20.0 & 2,934 & 19.4 & 2773 & 20.4 \\
\hline $70-79$ & 879 & 12.5 & 838 & 13.4 & 805 & 10.0 & 815 & 11.1 & 1,684 & 11.2 & 1653 & 12.2 \\
\hline$\geq 80$ & 400 & 5.7 & 369 & 5.9 & 392 & 4.8 & 330 & 4.5 & 792 & 5.2 & 699 & 5.1 \\
\hline Total & 7,031 & 46.5 & 6246 & 46.0 & 8,091 & 53.5 & 7345 & 54.0 & 15,122 & 100.0 & 13591 & 100.0 \\
\hline
\end{tabular}


Severe visual impairment (SVI): presenting VA of $<20 / 200$ to $20 / 400$ in the better eye.

Moderate visual impairment (Mod VI): presenting VA of $<20 / 63$ to $20 / 200$ in the better eye.

Mild visual impairment (Mild VI): presenting VA $<20 / 40$ to 20/63 in the better eye.

Normal/near normal $(\mathrm{NN})$ : presenting vision $\geq 20 / 40$ in the better eye.

\section{Statistical Analysis}

A customized database was created in commercial software (Access; Microsoft, Redmond, WA), and two trained data entry clerks entered the data. Data entered by one operator were checked by the second operator and corrections were made wherever necessary. Quality assurance procedures included a random verification of completed forms in the field and at the project office. All data were transferred to the International Centre for Eye Health for cleaning and analysis (Stata 10.0; Stata Corp, College Station, TX).

Prevalence estimates together with 95\% CIs for blindness and VI are presented. Multiple logistic regression analysis was performed to identify the risk factors for blindness and to estimate adjusted odds ratios (ORs). All the analyses took into account the clustering effect (design effect) due to the cluster sampling design adopted for the study. Missing values were excluded from all the analyses. $P<0.05$ were considered statistically significant. For estimating the magnitude of blindness among those aged $\geq 40$ years, the prevalence of blindness in each GPZ (along with the $95 \% \mathrm{CI}$ ) was used. To estimate the magnitude of blindness in the whole Nigerian population, prevalence estimates for the population aged $\leq 15$ years and those aged 16 to 49 years, quoted by the WHO were used. ${ }^{1}$ This method was used, as there are no other valid estimates of prevalence at the younger age groups from Nigeria. For the population $\geq 50$ years of age, the prevalence estimates generated by the present survey were used.

\section{Results}

A total of 15,122 persons aged $\geq 40$ years were enumerated, 13,599 (89.9\%) of whom were examined (Table 1). Response rates were similar across GPZs and ranged from $88.2 \%$ to $93.5 \%$. There were 1523 nonresponders, of whom $76.5 \%$ (1166) were not available for examination because they were either working at their farms or were away from the cluster, $22.9 \%$ (349) refused or left without complete examination and $0.5 \%$ (8) had mental disability. The age and sex profiles of those enumerated and those examined were similar (Table 2 ). There were marginally more younger women enumerated (40-49 years) than men (Table 2). Similarly, enumeration and examination rates were marginally lower for the older women than for the older men ( $\geq 80$ years).

The mean age of those examined was 55.9 years (SD \pm 12.4 ), being significantly higher in the men (56.7; SD \pm 12.5 ) than in the women $(55.2 ; \mathrm{SD} \pm 12.2 ; P=0.001)$. The mean age of those enumerated but not examined was 51.5 years (SD \pm 10.9). Among those not examined, the mean age of the men was 51.3 years $(\mathrm{SD} \pm 11.2)$ and of the women was 51.6 years $(\mathrm{SD} \pm 10.8)$. More than half of the sample examined were women $(54 \%)$. There was a higher proportion of women than men in the youngest age group ( $40-49$ years; Table 2$)$, and the age distribution of the men and women was significantly different $($ Pearson $=3.94 ; P<0.001)$.

Comparison of presenting (PVA) and best corrected visual acuity (BCVA) showed that $81 \%$ of participants who were categorized as blind based on PVA could not be improved by best correction after refraction, whereas $56.7 \%$ of those who had SVI and $56.9 \%$ of those with moderate VI could be improved (Table 3).

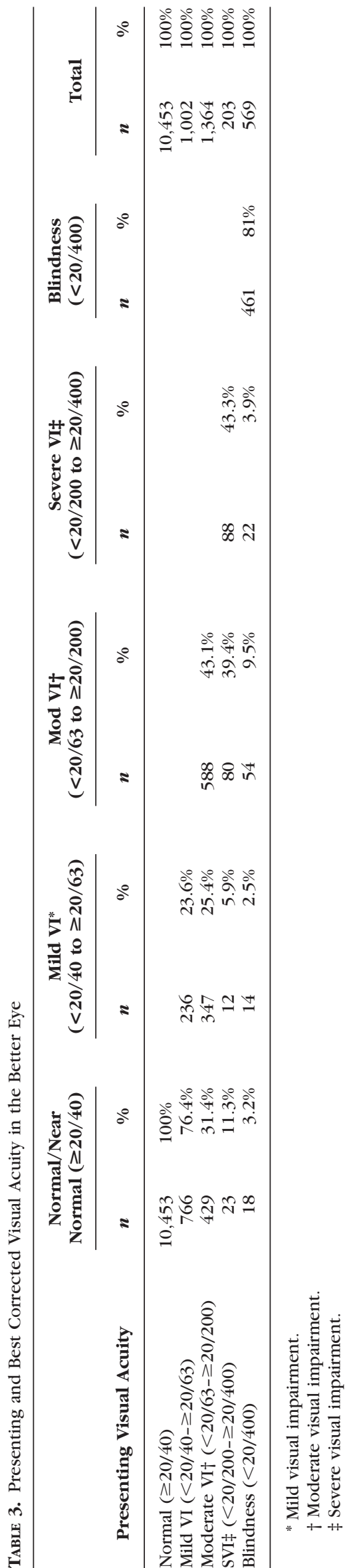


The prevalence of blindness in the sample using PVA was 4.2\% (95\% CI: 3.8\%-4.6\%; Table 4), and the prevalence of SVI was $1.5 \%$ (95\% CI: 1.3\%-1.7\%). Based on BCVA, 3.4\% (95\% CI: 3.0\%-3.8\%) were blind, $0.8 \%$ (95\% CI: $0.7 \%-1.0 \%$ ) had SVI, 5.3\% (95\% CI: $4.9 \%-5.8 \%$ ) had moderate VI, $4.5 \%$ (95\% CI: $4.1 \%-4.9 \%$ ) had mild VI, and $86 \%$ (95\% CI: $85.2 \%-86.8 \%$ ) were categorized as normal/near normal. The prevalence of blindness among those aged $\geq 50$ years was $5.47 \%(476 / 8702)$ and $9.3 \%$ (476/5125) among those aged $\geq 60$ years.

Univariate analysis revealed that the prevalence of blindness based on PVA increased significantly with increasing age, from $0.8 \%$ (95\% CI: $0.5 \%-1.1 \%)$ at 40 to 49 years to $23.3 \%(95 \%$ CI: $20.2 \%-26.7 \%)$ among those aged $\geq 80$ years $(F=222.72$;
$P<0.001 ;$ Table 4). Significant differences were also observed in relation to sex with females having a higher prevalence $(F=22.23 ; P<0.001)$ and literacy as participants who could not read or write had a higher prevalence compared with those who could $(F=68.82 ; P<0.001)$. There were also differences by administrative zone: participants living in the South West had the lowest prevalence of blindness $(2.8 \%$; 95\% CI: $2.2 \%-3.5 \%)$, whereas those in the North East GPZ had the highest (6.1\%; 95\% CI: 4.7\%-7.9\%) $(F=$ $6.36 ; P<0.001)$. The prevalence of blindness did not differ by urban/rural place of usual residence $(F=1.62 ; P=$ $0.1785)$. Similar findings were also observed in relation to SVI (Table 4).

TABLE 4. Association between Sociodemographic Variables and Presenting Visual Acuity in the Better Eye

\begin{tabular}{|c|c|c|c|c|c|}
\hline Parameters & $\begin{array}{c}\text { Normal/Near Normal } \\
n(\%) \\
{[95 \% \mathrm{CI}]}\end{array}$ & $\begin{array}{c}\text { Mild VI } \\
n(\%) \\
{[95 \% \mathrm{CI}]}\end{array}$ & $\begin{array}{c}\text { Mod VI } \\
n(\%) \\
{[95 \% \mathrm{CI}]}\end{array}$ & $\begin{array}{c}\text { Severe VI } \\
n(\%) \\
{[95 \% \mathrm{CI}]}\end{array}$ & $\begin{array}{c}\text { Blind } \\
n(\%) \\
{[95 \% \mathrm{CI}]}\end{array}$ \\
\hline Total & $\begin{array}{c}10,455(76.9) \\
{[75.8-77.9]}\end{array}$ & $\begin{array}{r}1,002(7.4) \\
{[6.9-7.9]}\end{array}$ & $\begin{array}{c}1,364(10.0) \\
{[9.4-10.7]}\end{array}$ & $\begin{array}{c}203(1.5) \\
{[1.3-1.7]}\end{array}$ & $\begin{array}{l}569(4.2) \\
{[3.8-4.6]}\end{array}$ \\
\hline \multicolumn{6}{|l|}{ Age (y) } \\
\hline $40-49$ & $4,662(95.3)$ & $103(2.1)$ & $82(1.7)$ & $\begin{array}{l}6(0.1) \\
{[0.004-0.3]}\end{array}$ & $\begin{array}{l}37(0.8) \\
{[0.5-1.1]}\end{array}$ \\
\hline $50-59$ & $3,076(86.0)$ & $232(6.5)$ & $189(5.3)$ & $\begin{array}{l}25(0.7) \\
{[0.5-1.0]}\end{array}$ & $\begin{array}{l}56(1.6) \\
{[1.2-2.1]}\end{array}$ \\
\hline $60-69$ & $1,825(65.8)$ & $319(11.5)$ & $446(16.1)$ & $\begin{array}{l}52(1.9) \\
{[1.4-2.5]}\end{array}$ & $\begin{array}{l}131(4.7) \\
{[3.9-5.8]}\end{array}$ \\
\hline $70-79$ & $719(43.5)$ & $243(14.7)$ & $444(26.9)$ & $\begin{array}{l}65(3.9) \\
{[3.1-4.9]}\end{array}$ & $\begin{array}{c}182(11.0) \\
{[9.6-12.6]}\end{array}$ \\
\hline$\geq 80$ & $173(24.7)$ & $105(15.0)$ & $203(29.0)$ & $\begin{array}{l}55(7.9) \\
{[6.1-10.0]}\end{array}$ & $\begin{array}{c}163(23.3) \\
{[20.2-26.7]} \\
\text { F } 222.72 \\
P<0.001\end{array}$ \\
\hline \multicolumn{6}{|l|}{ Sex } \\
\hline Male & $5,023(80.4)$ & $362(5.8)$ & $522(8.4)$ & $\begin{array}{l}92(1.5) \\
{[1.2-1.8]}\end{array}$ & $\begin{array}{l}248(4.0) \\
{[3.5-4.6]}\end{array}$ \\
\hline Female & $5,432(73.9)$ & $640(8.7)$ & $842(11.5)$ & $\begin{array}{l}111(1.1) \\
\quad[1.2-1.8]\end{array}$ & $\begin{array}{c}321(4.4) \\
{[3.9-4.9]} \\
\text { F } 22.23 \\
P<0.001\end{array}$ \\
\hline \multicolumn{6}{|l|}{ GPZ } \\
\hline South West & $2,170(79.5)$ & $195(7.1)$ & $263(9.6)$ & $\begin{array}{l}24(0.9) \\
{[0.6-1.3]}\end{array}$ & $\begin{array}{l}76(2.8) \\
{[2.2-3.5]}\end{array}$ \\
\hline South South & $1,351(72.9)$ & $154(8.3)$ & $254(13.7)$ & $\begin{array}{l}33(1.8) \\
{[1.2-2.5]}\end{array}$ & $\begin{array}{l}60(3.2) \\
{[2.4-4.4]}\end{array}$ \\
\hline South East & $1,159(69.7)$ & $174(10.5)$ & $218(13.1)$ & $\begin{array}{l}34(2.0) \\
{[1.5-2.8]}\end{array}$ & $\begin{array}{l}77(4.6) \\
{[3.6-5.9]}\end{array}$ \\
\hline North Central & $1,648(81.2)$ & $126(6.2)$ & $144(7.1)$ & $\begin{array}{l}35(1.7) \\
{[1.2-2.5]}\end{array}$ & $\begin{array}{l}76(3.7) \\
{[3.0-4.7]}\end{array}$ \\
\hline North West & $2,837(78.9)$ & $233(6.5)$ & $297(8.3)$ & $\begin{array}{l}53(1.5) \\
{[1.1-1.9]}\end{array}$ & $\begin{array}{l}174(4.8) \\
{[4.1-5.8]}\end{array}$ \\
\hline North East & $1,290(74.6)$ & $120(6.9)$ & $188(10.9)$ & $\begin{array}{l}24(1.4) \\
{[1.0-2.0]}\end{array}$ & $\begin{array}{c}106(6.1) \\
{[4.7-7.9]} \\
\text { F } 6.36 \\
P<0.001\end{array}$ \\
\hline \multicolumn{6}{|l|}{ Place of residence } \\
\hline Urban & $2,408(78.9)$ & $210(6.9)$ & $272(8.9)$ & $\begin{array}{l}44(1.4) \\
{[1.0-2.0]}\end{array}$ & $\begin{array}{l}117(3.8) \\
\quad[3.1-4.7]\end{array}$ \\
\hline Rural & $8047(76.3)$ & $792(7.5)$ & $1,092(10.4)$ & $\begin{array}{l}159(1.5) \\
{[1.3-1.8]}\end{array}$ & $\begin{array}{c}452(4.3) \\
{[3.8-4.8]} \\
\text { F } 1.62 \\
P=0.18\end{array}$ \\
\hline \multicolumn{6}{|l|}{ Literacy* } \\
\hline Reads and writes easily & $2,626(89.5)$ & $115(3.9)$ & $134(4.6)$ & $\begin{array}{l}16(0.6) \\
{[0.3-0.9]}\end{array}$ & $\begin{array}{l}43(1.5) \\
{[1.0-2.1]}\end{array}$ \\
\hline Reads and writes with difficulty & $2,544(85.2)$ & $150(5.0)$ & $188(6.3)$ & $\begin{array}{l}26(0.9) \\
{[0.6-1.3]}\end{array}$ & $\begin{array}{l}78(2.6) \\
{[1.9-3.5]}\end{array}$ \\
\hline Illiterate & $5,276(68.9)$ & $736(9.6)$ & $1,042(13.6)$ & $\begin{array}{l}161(2.1) \\
\quad[1.8-2.5]\end{array}$ & $\begin{array}{l}446(5.8) \\
{[5.3-6.5]}\end{array}$ \\
\hline
\end{tabular}

\footnotetext{
* Literacy status could not be determined in 12 individuals.
} 
TABLE 5. Risk Factors for Blindness

\begin{tabular}{lrc}
\hline & & Blindness \\
\cline { 2 - 3 } \multicolumn{1}{c}{ Risk Factors } & $\boldsymbol{n}$ & Adjusted OR* (95\% CI) \\
& & \\
Age (y) & 93 & Reference \\
40-59 & 131 & $4.5(3.3-6.1)$ \\
60-69 & 182 & $11.3(8.6-15.0)$ \\
$70-79$ & 163 & $28.1(20.7-38.1)$ \\
$\geq 80$ & & \\
Sex & 248 & Reference \\
Male & 321 & $1.3(1.1-1.6)$ \\
Female & & \\
GPZ & 76 & Reference \\
South West & 60 & $1.3(0.8-1.9)$ \\
South South & 77 & $1.5(1.1-2.1)$ \\
South East & 76 & $1.6(1.1-2.3)$ \\
North Central & 174 & $2.5(1.8-3.4)$ \\
North West & 106 & $3.2(2.2-4.7)$ \\
North East & & \\
Place of residence & 117 & Reference \\
Urban & 452 & $1.0(0.8-1.4)$ \\
Rural & & \\
Literacy & 43 & Reference \\
Reads and writes easily & & $1.7(1.1-2.6)$ \\
Reads and writes with difficulty & 78 & $(1.4-3.0)$ \\
Illiterate & 446 & \\
\hline
\end{tabular}

${ }^{*}$ Adjusted for age and sex.

In multivariate analysis, age, sex, administrative zones, and literacy remained significantly associated with blindness after adjustment for age and sex (Table 5). Individuals aged $\geq 80$ years had a 28 times higher risk (95\% CI: 20.7-38.1) of being blind than the youngest participants had. The women had a $30 \%$ higher risk of blindness than the men (95\% CI: 1.1-1.6), while people residing in the North East GPZ had a 3.2 (95\% CI: 2.2-4.7) times higher risk than those in the South West. Participants who could not read or write, had double the risk of being blind, compared with those who could read and write easily.

The magnitude of blindness among adults aged $\geq 40$ years and for all ages was estimated (Table 6). Based on the survey findings, it is estimated that 1.13 million individuals aged $\geq 40$ years are currently blind in Nigeria (95\% CI: 1.03-1.25 million). The North West GPZ harbors the largest number of adults with blindness in Nigeria (28.6\%) being the zone with the largest population (Fig. 1). It was also observed that 2.7 million adults aged $\geq 40$ years had moderate VI and an additional 0.4 million adults had SVI. Thus, a total of 4.25 million adults aged $\geq 40$ years in Nigeria suffer moderate or SVI or blindness (Table 6).

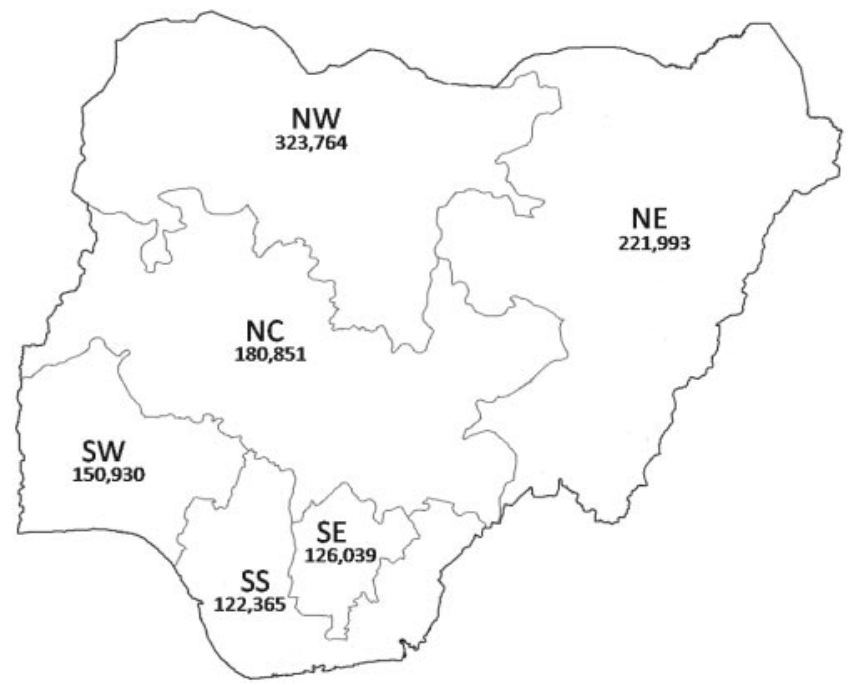

FIGURE 1. The estimated number of adults with blindness in different geopolitical zones in Nigeria. NW, North West; NE, North East; NC, North Central; SW, South West; SE, South East; and SS, South South.

\section{DisCussion}

National surveys in Africa have been undertaken in only a few countries, such as like Benin, Ethiopia, Gambia, and Tunisia. ${ }^{28-31}$

In the present survey, response rates were high in all GPZs, which means that the findings can be generalized to the country as a whole. The proportion of women aged $\geq 40$ years in the sample (54\%) was higher than the proportion of women for this age group, reported for all of Nigeria in 2005 $(50.04 \%) . .^{32}$ There was a higher proportion of women than men aged 40 to 49 years in the examined population. The mean age of nonresponders and those who refused was lower than of those examined, perhaps because a larger proportion of the younger men were not available for examination, as they were working away from home.

The data presented in this article along with the data on the causes of blindness (which will be available in a subsequent paper) will allow policy makers and program planners in $\mathrm{Ni}$ geria to plan for control of blindness in a more effective manner and to monitor progress toward realization of the goals of VISION 2020: The Right to Sight. The Nigerian survey also provides valid population-based data to help the Ministries of Health and international nongovernment organizations in planning, implementing and monitoring eye care programs in similar geoeconomic areas of Africa and access to eye care services (West and Central Africa).

Table 6. Estimated Number of Visually Impaired and Blind Persons Aged $\geq 40$ Years in the GPZs

\begin{tabular}{|c|c|c|c|c|c|c|c|c|c|}
\hline \multirow[b]{2}{*}{ GPZ } & \multicolumn{3}{|c|}{ Blindness } & \multicolumn{3}{|c|}{ SVI } & \multicolumn{3}{|c|}{ Moderate VI } \\
\hline & $\begin{array}{c}\text { Prev. } \\
(\%)\end{array}$ & $\begin{array}{c}\text { Estimated } \\
\text { No. }\end{array}$ & 95\% CI & $\begin{array}{c}\text { Prev } \\
(\%)\end{array}$ & $\begin{array}{c}\text { Estimated } \\
\text { No. }\end{array}$ & 95\% CI & $\begin{array}{c}\text { Prev. } \\
(\%)\end{array}$ & $\begin{array}{c}\text { Estimated } \\
\text { No. }\end{array}$ & 95\% CI \\
\hline North West & 4.84 & 323,764 & $270,765-385,756$ & 1.48 & 98,618 & $74,878-129,700$ & 8.27 & 552,632 & $483,365-630,447$ \\
\hline North East & 6.14 & 221,993 & $171,076-286,814$ & 1.39 & 50,263 & $34,721-72,698$ & 10.89 & 393,725 & $330,577-466,932$ \\
\hline North Central & 3.75 & 180,851 & $142,916-228,376$ & 1.72 & 83,287 & $56,973-121,189$ & 7.10 & 342,665 & $278,107-421,023$ \\
\hline South West & 2.79 & 150,930 & $120,813-187,991$ & 0.88 & 47,662 & $31,422-72,054$ & 9.64 & 522,300 & $452,371-601,898$ \\
\hline South East & 4.63 & 126,039 & $98482-160,781$ & 2.05 & 55,654 & $39,991-77,262$ & 13.12 & 356,839 & $298,166-424,941$ \\
\hline South South & 3.24 & 122,365 & $89,515-166,943$ & 1.78 & 67,301 & $47,213-95,558$ & 13.71 & 518,012 & $444,931-600,543$ \\
\hline Nigeria & 4.19 & $1,132,295$ & $1,027,738-1,246,808$ & 1.49 & 403,965 & $351,595-465,187$ & 10.04 & $2,714,324$ & $2,542,299-2,896,598$ \\
\hline
\end{tabular}

Prev., prevalence. 
The study showed that 4.25 million adults aged $\geq 40$ years in Nigeria have moderate or SVI or blindness. The $>1$ million adults with blindness in Nigeria are therefore in urgent need of attention, as are the additional 3 million with severe and moderate VI, who would benefit from eye care services. This million-plus pool of persons with blindness also impinges on national productivity, as it entails not only a loss of income of affected individuals but also lost wages and time of those caring for them. In a resource-constrained country like Nigeria, priorities should be set with specific attention paid to the older population, as an overwhelming proportion of blindness is concentrated among this segment of the population.

The WHO global data on blindness for 2002 categorized Nigeria along with a group of other countries in the region as having an estimated prevalence of blindness of $9 \%$ among those aged $\geq 50$ years and $1 \%$ for the population of all ages. ${ }^{1}$ The present survey showed that the prevalence of blindness among those aged $\geq 50$ years was $5.47 \%$ and therefore it may be necessary to revise the WHO estimates of blindness in Africa.

The detailed survey revealed a much higher prevalence of blindness than generally observed in Rapid Assessment of Avoidable Blindness (RAAB) surveys in other African countries (i.e., Western Rwanda, ${ }^{33}$ Cameroon, ${ }^{34}$ and Kenya ${ }^{35}$ ). However, a rapid assessment of cataract blindness, nearly a decade ago, in one State (Katsina) ${ }^{21}$ in North Central Nigeria found that the prevalence of blindness among those aged $\geq 40$ years was $8.2 \%$ which is higher than the prevalence among those of a similar age in the North Central GPZ (3.7\%) in the present survey. The results of a recently concluded national survey in Ethiopia that included all age groups showed that the prevalence of blindness among those aged $\geq 60$ years was $14.8 \%{ }^{31}$ This was much higher than the prevalence among persons of a comparable age group in Nigeria in the present survey, where it was $9.3 \%$.

The prevalence of blindness among adults in Nigeria (4.2\% $\geq 40$ years; $6.5 \% \geq 50$ years) is lower than in Pakistan $(5.1 \%$ aged $\geq 40$ years; $7 \% \geq 50$ years), ${ }^{25}$ higher than in Bangladesh $(2.3 \% \geq 40$ years; $3.9 \% \geq 50$ years $),{ }^{26}$ and similar to that in India $\left(5.34 \% \geq 50\right.$ years). ${ }^{27}$ The surveys in these three highly populous Asian countries used detailed methodology similar to that used in Nigeria, and therefore comparisons may be more appropriate. Differences in prevalence of blindness between the different countries in Africa and Asia could be due to differences in the causes of blindness, access to eye care services, or differences in life expectancy.

Data from the present survey are the first step in the planning process and information on the causes of blindness and VI are needed to prepare concrete strategies for the elimination of avoidable blindness in Nigeria. Strategic planning should be decentralized, as there are significant differences across the GPZs in Nigeria.

\section{References}

1. Resnikoff S, Pascolini D, Etya'ale D, et al. Global data on visual impairment in the year 2002. Bull World Health Org. 2004;82: 844-851.

2. Federal Republic of Nigeria: 2006 population census. Available at http://www.nigerianstat.gov.ng/Connections/Pop2006.pdf. Accessed on September 22, 2008.

3. World Bank Nigeria: Country Brief. http://web.worldbank.org/ WBSITE/EXTERNAL/COUNTRIES/AFRICAEXT/NIGERIAEXTN/ 0, menuPK:368906 pagePK:141132 piPK:141107 theSitePK: 368896,00.html. Accessed March 13, 2009.

4. Dawodu OA, Osahon AI, Emifoniye E. Prevalence and causes of blindness in Otibhor Okhae Teaching Hospital, Irrua, Edo State, Nigeria. Opbthalmic Epidemiol. 2003;10:323-330.
5. Oluleye TS, Ajaiyeoba AI, Akinwale MO, Olusanya BA. Causes of blindness in Southwestern Nigeria: a general hospital clinic study. Eur J Ophthalmol. 2006;16:604-607.

6. Abiose A, Murdoch I, Babalola O, et al. Distribution and aetiology of blindness and visual impairment in mesoendemic onchocercal communities, Kaduna State, Nigeria. Br J Opbthalmol. 1994;78:813.

7. Umeh RE, Chijioke CP, Okonkwo PO. Eye disease in an onchocerciasis-endemic area of the forest-savannah mosaic region of Nigeria. Bull World Health Organ. 1996;74:95-100.

8. Mpyet C, Solomon AW. Prevalence and causes of blindness and low vision in leprosy villages of north eastern Nigeria. $\mathrm{BrJOph}$ thalmol. 2005;89:417-419.

9. Onakpoya OH, Adeoye AO, Akinsola FB, Adegbehingbe BO. Prevalence of blindness and visual impairment in Atakunmosa West Local Government area of south-western Nigeria. Tanzan Health Res Bull. 2007;9:126-131.

10. Adegbehingbe BO, Majengbasan TO. Ocular health status of rural dwellers in south-western Nigeria. Aust J Rural Health. 2007;15: 269-272.

11. Adegbehingbe BO, Fajemilehin BR, Ojofeitimi EO, Bisiriyu LA. Blindness and visual impairment among the elderly in Ife-Ijesha zone of Osun State, Nigeria. Indian J Ophthalmol. 2006;54:59-62.

12. Patrick-Ferife G, Ashaye AO, Qureshi BM. Blindness and low vision in adults in Ozoro, a rural community in Delta State, Nigeria. Niger J Med. 2005;14:390-395.

13. Adeoti CO. Prevalence and causes of blindness in a tropical African population. West Afr J Med. 2004;23:249-252.

14. Ezepue UF. Magnitude and causes of blindness and low vision in Anambra State of Nigeria (results of 1992 point prevalence survey). Public Health. 1997;111:305-309.

15. Adeoye A. Survey of blindness in rural communities of southwestern Nigeria. Trop Med Int Health. 1996;1:672-676.

16. Nwosu SN. Blindness and visual impairment in Anambra State, Nigeria. Trop Geogr Med. 1994;46:346-349.

17. Nigerian National Bureau of Statistics, Poverty Profile 2006. Available at http://www.nigerianstat.gov.ng/nlss/2006/survey0/ outputInformation/prereport.pdf. Accessed March 13, 2009.

18. Dineen B, Gilbert CE, Rabiu MM, et al. The Nigeria National Blindness and Visual Impairment Survey: rationale, objectives and detailed methodology. BMC Opbthalmology. 2008;8:17.

19. Bourne RA, Dineen B, Modasser Ali S, Noorul Haq DM, Johnson GJ. The National Blindness and Low Vision Prevalence Survey of Bangladesh: research design, eye examination methodology and results of the pilot survey. Ophthalmic Epidemiol. 2002;9:119-132.

20. Bourne RA, Dineen B, Jadoon Z, et al. The Pakistan National Eye Survey Study Group. The Pakistan National Blindness and Visual Impairment Survey: research design, eye examination methodology and results of the pilot study. Opbthalmic Epidemiology. 2005; 12:321-333.

21. Rabiu MM. Cataract blindness and barriers to uptake of cataract surgery in a rural community of northern Nigeria. $\mathrm{Br} J$ Opbthalmol. 2001;85:776-780.

22. Rosser DA, Laidlaw DA, Murdoch IE. The development of a "reduced logMAR" visual acuity chart for use in routine clinical practice. Br J Ophthalmol. 2001;85:432-436.

23. Bourne RR, Rosser DA, Sukudom $P$, et al. Evaluating a new logMAR chart designed to improve visual acuity assessment in population based surveys. Eye. 2003;17:754-758.

24. http://www.who.int/blindness/Change $\% 20$ the $\% 20$ Definition \%20of\%20Blindness.pdf. Accessed March 13, 2009.

25. Jadoon MZ, Dineen B, Bourne RRA, et al. Prevalence of blindness and visual impairment in Pakistan: The Pakistan National Blindness and Visual Impairment Survey. Invest Opbthalmol Vis Sci. 2006; 47:4749-4755.

26. Dineen BP, Bourne RRA, Ali SM, Huq DMN, Johnson GJ. Prevalence and causes of blindness and visual impairment in Bangladeshi adults: results of the National Blindness and Low Vision Survey of Bangladesh. Br J Ophthalmol. 2003;87:820-828.

27. Murthy GVS, Gupta SK, Bachani D, Jose R, John N. Current estimates of blindness in India. Br J Ophthalmol. 2005;89:257-260. 
28. Faal H, Minassian DC, Dolin PJ, Mohamed AA, Ajewole J, Johnson GJ. Evaluation of a national eye care programme: resurvey after 10 years. Br J Ophthalmol. 2000;84:948-951.

29. Negrel AD, Avognon Z, Minassian DC, Babaqbeto M, Oussa G, Bassabi S. Blindness in Benin. Med Trop (Mars). 1995;55:409414 .

30. Ayed S, Négrel AD, Nabli M, Kamel N, Jebri AM, Siddhom M Prevalence and causes of blindness in the Tunisian Republic: results of a national survey conducted in 1993. Tunisian Team on the Evaluation of Blindness. Sante. 1998;8:275-282.

31. Berhane Y, Worku A, Bejiga A et al. Prevalence and causes of blindness and low vision in Ethiopia. Ethiopian J Health Dev. 2007;21:204-210.
32. U.S. Census Bureau International Database http://www.census. gov/cgi-bin/ipc/idbpyry.pl?cty $=$ NI\&maxp $=12904386 \& \operatorname{maxa}=$ $100 \&$ max $=250 \& y r=2005 \&$ submit $=$ Submit + Query. Accessed March 13, 2009.

33. Mathenge W, Nkurikiye J, Limburg H, Kuper H. Rapid assessment of avoidable blindness in Western Rwanda: blindness in a postconflict setting. PLoS Med. 2007; 4:e217.

34. Oye JE, Kuper H. Prevalence and causes of blindness and visual impairment in Limbe urban area, South West Province, Cameroon. Br J Ophthalmol. 2007;91 (11):1435-1439.

35. Mathenge W, Kuper $\mathrm{H}$, Limburg $\mathrm{H}$, et al. Rapid assessment of avoidable blindness in Nakuru district, Kenya. Ophthalmology. 2007;114:599-605. 